\title{
Pamięci Profesora Józefa Matuszewskiego
}

Publikacje składające się na kolejny tom (IX i X) Studiów $z$ dziejów państwa i prawa polskiego przygotowane zostały przez historyków nie tylko prawa $\mathrm{z}$ różnych polskich ośrodków naukowych, jako hold składany - niestety - już tylko pamięci jednego $\mathrm{z}$ najwybitniejszych polskich historyków prawa $\mathrm{XX}$ stulecia.

Zmarły 14 października 2003 r. Józef Matuszewski - profesor Uniwersytetu Adama Mickiewicza w Poznaniu, a następnie Uniwersytetu Lódzkiego - doczekał się wielu dowodów uznania jeszcze za swojego długiego życia: uhonorowany Medalem Oswalda Balzera i licznymi odznaczeniami państwowymi, byl doktorem honoris causa Uniwersytetu Lódzkiego, Jemu dedykowany został jeden z tomów "Czasopisma Prawno-Historycznego"1, i o Nim czytać można w jednym z zeszytów wydawanego przez Łódzkie Towarzystwo Naukowe cyklu Sylwetki Lódzkich Uczonych ${ }^{2}$ a czẹść znakomitego dorobku (114 prac na 2046 stronach) udostępniło ponownie Wydawnictwo Uniwersytetu Łódzkiego w pięciu, dziś już praktycznie nieosiągalnych, tomach Pism wybranych.

Przystępując do gromadzenia i opracowywania materiałów, których Autorzy zechcieli laskawie dedykować pamięci Profesora Józefa Matuszewskiego, Redakcja zrezygnowała $\mathrm{z}$ tradycyjnego w podobnych przypadkach zamierzenia przedstawienia Jego postaci $\mathrm{i}$ dorobku. Czyniono to już niejednokrotnie ${ }^{3}$, a tuż po śmierci Profesora ukazało się w rozmaitych periodykach kilka starannie przygotowanych, podkreślających najważniejsze dokonania, nekrologów. Ponowne zatem przypomnienie tych zasług wydawało się mało racjonalne, zwłaszcza że naszym zamysłem było nawiązanie do dewizy wyznawanej całym życiem Profesora: służba nauce ${ }^{4}$. Poświęcał swe życie pracy naukowej tak dalece, że za zbędną stratę czasu uważał wszystko, co

${ }^{1} 1988$, t. XL, z. 2 w sześćdziesięciolecie pracy naukowej, w którym B. L esiński swój tekst O twórczości naukowej Józefa Matuszewskiego poprzedził wskazaniem: Opus magnum et laudabile.

${ }^{2}$ Sylwetki Lódzkich Uczonych. Profesor Józef Matuszewski, z. 31, LTN 1996.

${ }^{3}$ Por. ostatnią rozmowę przeprowadzoną przez H. Ols zew ski eg o i opublikowaną w $\mathrm{CPH}$ 2002 , t. LIV, z. 1, s. 399-408.

${ }^{4}$ Jak pisał B. Lesiński, Profesor Józef Matuszewski był nieublaganym wrogiem blichtru i blagi w nauce; Sylwetki Lódzkich Uczonych..., s. 12. 
nie służyło rozwojowi Jego badań. Stąd też - gwoli przykładu - zapewne obok trudności obiektywnych, niechętny był wyjazdom zagranicznym (po 1945 r. pozwolił sobie zaledwie na kilka wyjazdów służbowych do Francji, Austrii i Czech).

Zgromadziliśmy w tym podwójnym tomie prace historyków kilku pokoleń - przyjaciół, uczniów i kolegów, a także młodych adeptów, którzy nie mieli już okazji do osobistego kontaktu z Uczonym. Zmarły w 93. roku życia Józef Matuszewski kontynuował swą umiłowaną działalność badawczą do końca, pozostawiając kilka prac niedokończonych, których już nikt nie potrafi podjąć. Dedykowanie temu znakomitemu przede wszystkim mediewiście prac nad dziejami państwa i prawa polskiego obejmujących zarówno średniowiecze, jak i czasy nowożytne, a nawet lata dla Zmarłego współczesne - to wyraz kontynuacji, ale także postępu i umiejętności dostosowania się dyscypliny do zmieniającej się rzeczywistości. Kiedy Profesor zaczynał swoją życiową przygodę z historią państwa i prawa, wkraczał na obszary niemal dziewicze, podejmował pracę w ramach dyscypliny dopiero rozwijającej się, gdy badawcza dyrektywa wyczerpania literatury nie budziła wątpliwości. U schylku swego życia musiał bojkotować zalew wtórnej literatury, najchętniej kierując swe badania na obszary dopiero otwierane przez nowe edycje źródel ${ }^{5}$. Naukowo obecny we wszystkich dotychczas opublikowanych tomach, po raz ostatni bezpośrednio przyczynia się - tym razem swym autorytetem - do kształtu Studiów z Dziejów Państwa i Prawa Polskiego.

REDAKCJA

${ }^{5}$ Taką bazą dla znacznej części prac okazało się najpierw wydawnictwo Schlesisches Urkundenbuch, a następnie Decreta iuris supremi Magdeburgensis castri Cracoviensis. 